\title{
顔貌写真撮影法の考案
}

- 3 面顔貌規格同時撮影法

\section{清 野尚* \\ Photographic Methods of the Face in Clinical Practice and the Concept of Simultaneous Frontal, Angular and Lateral Photographs}

\section{Takashi Seino*}

Together with a diversification of the clinical dental needs of patients, there has been a tendency for simultaneous increases in the extent of the clinician's responsibilities in terms of both quality and quantity. In the field of clinical photography, for cases that had been handled with simple intraoral photographs in normal treatment, recently pictures are often taken of the face and lips including the teeth. In particular there has been a gradual increase in the need for facial photographs, and there has been a continual increase in the demand for pictures that provide a greater amount of information than has been acquired with conventional methods.

The actual clinical treatment of gnathology, which includes responsibility for the entire oral cavity, must be carried out by dealing with the acquisition of a variety of information associated with the patient's face. Consequently, acquisition of objective data requires high quality facial photographic methods. I will introduce a facial photographic method I devised that can simultaneously photograph the frontal, angular and lateral face of patients.

\section{はじめに}

臨床に際して口腔内の現症, 治療経過の写真記 録の一手段として, 口腔内写真撮影は頻繁に行わ れているが1 3), 顔貌写真撮影の機会はこれに比べ て少なく，確立した方法も少ないようである。

ことに, 顔貌写真は診療録への口腔内所見のプ ロトコール記載と同様, 口腔外所見として,こと に補経, 矯正ならびに口腔外科領域での術前・術 中・術後の経過記録, 顎咬合学の臨床実践に際し

\footnotetext{
* 福岡県福岡市開業
}

て重要な意義を有する.すなわち顔貌の形態, 対 称性, 表情ならびに顔面調和などを観察する場合 に有力な情報提供源となり，客観的視覚資料とし ての臨床的意義はきわめて大きなものがある。し かしながら，顔貌写真として平板ミラー反射によ る正貌・側貌同時撮影法などが紹介されている が6), 三面顔貌規格写真撮影法に関する歯科臨床 での報告はきわめて少ない。

最近の歯科治療が，その患者の顔貌，表情なら びに性格までも変えることが可能である事実を著 者らは経験している事から, 顔貌写真撮影法を確 立する事は必須のものである。

今回著者は, すでに著者らが確立している顔貌 

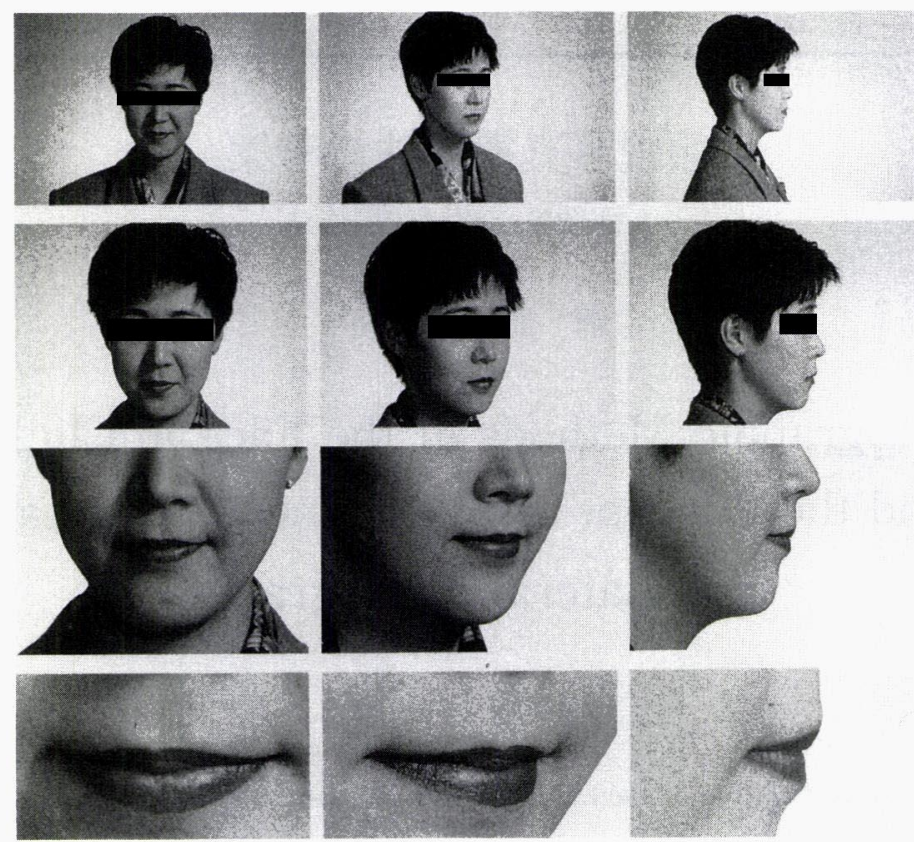

図 1 顔貌規格写真 正視撮影画像

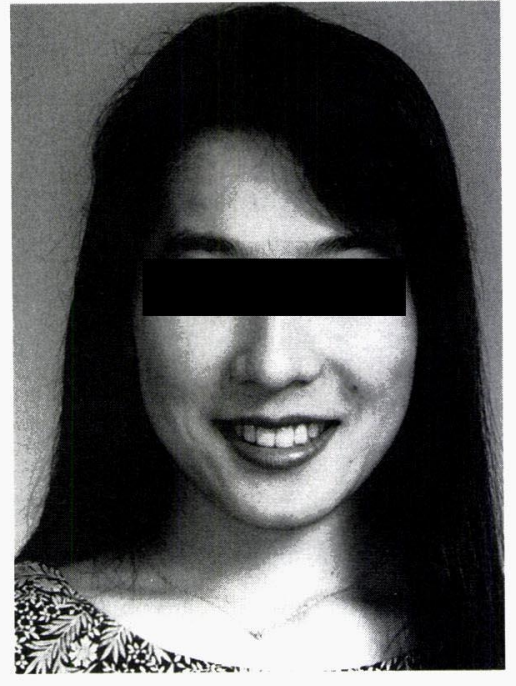

図 2 自由(一般)撮影

リラックスした自然な表情

写真撮影法を一歩前進させて, マルチ・ケーブル レリーズとストロボを組合せた正貌， $45^{\circ}$ 斜側貌 (以下, 斜貌と略記す) ならびに側貌の 3 面規格同 時撮影法を考案, 開発し, 臨床的成果を得たので, その機構ならびにその実際について報告し, 臨床 家各位の参考にする次第である。

\section{撮影ならびに照明関連装置}

1. カメラおよびレンズ

ペンタックス Z10, ペンタックス-F ZOOM 28 〜105 mm 電磁レリーズ方式を備えた機, 3 台を 用いた。

すなわち，一本のレンズでロ腔内クローズアッ プから顔貌ならびに上半身までの写真撮影には使 用レンズの特性から兼用は無理であるので, 望遠 ズームレンズを選択した。

\section{2.ストロボ装置}

顔貌写真の照明装置として従来よりリングスト ロボが頻用されているが，これは被写体に影を作 らないのが特長であるので, 顔貌撮影では光が当 たりすぎて, 顔面がフラットな画像に成りがちで ある。

\section{3. 反射板（アンブレラ）}

リングストロボの欠点を補うためにアンブレラ を用いると, 立体感のある自然な顔貌写真が得ら れる。こうすることにより光をバウンドさせ，ソ 


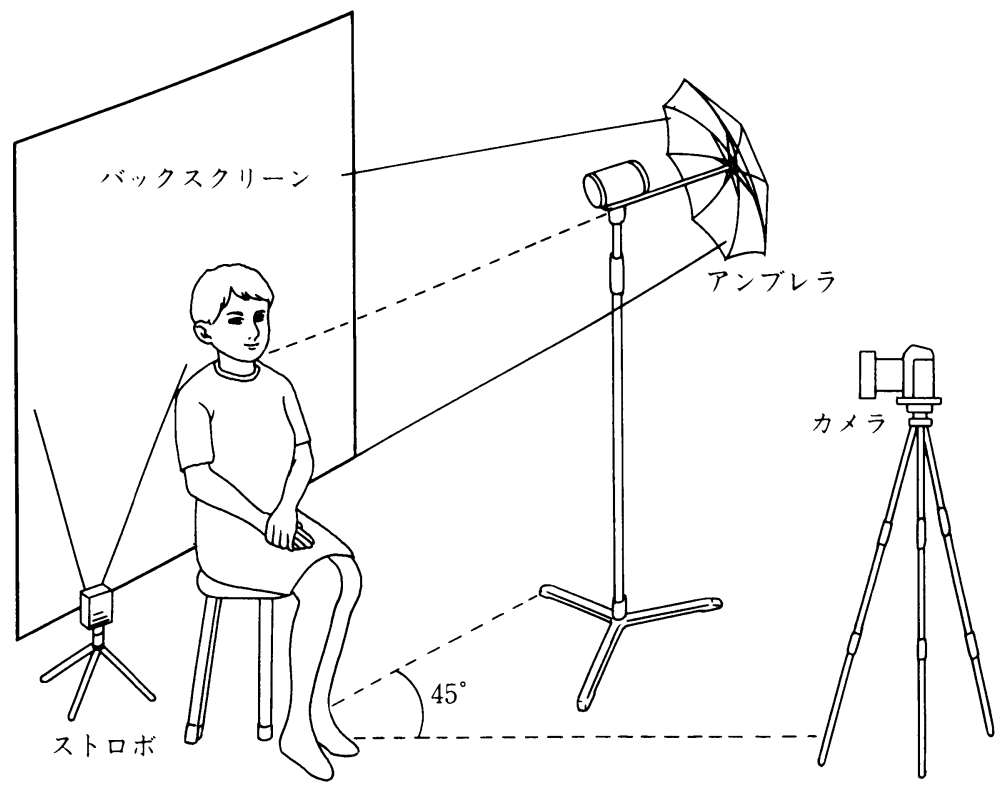

図 3 通常の写真撮影法 (理解図)

カメラ, ストロボ, アンブレラおよびバック・スクリーンの配置

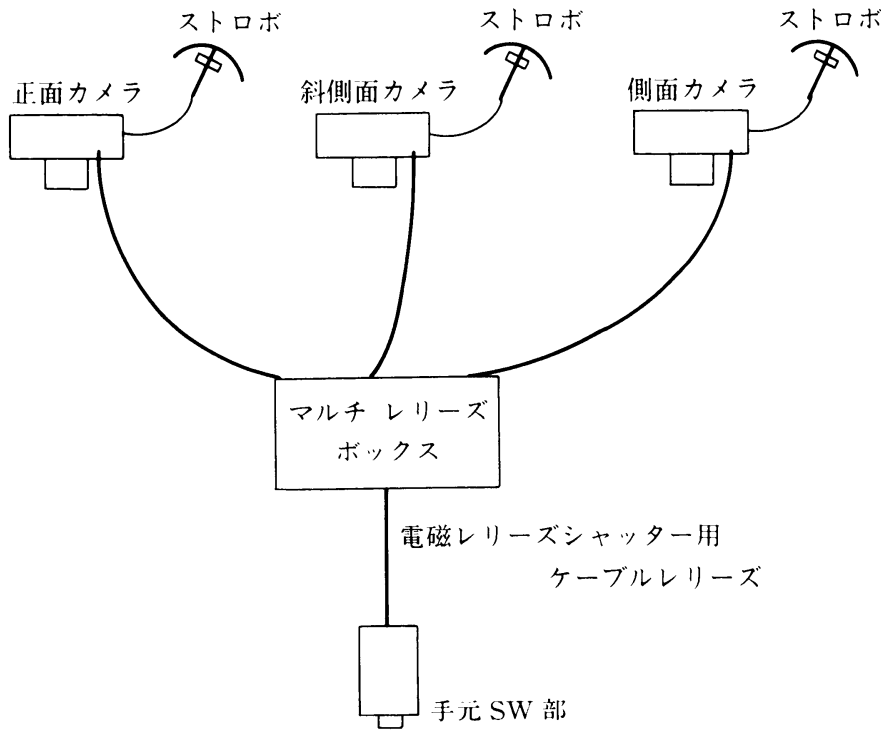

図 4 マルチ・ケーブルレリーズ(理解図)

各カメラとパラレルに接続したレリーズ

フトな間接光により顔面の凹凸が立体的に表現で きる利点がある.リングストロボ 1 灯のみの直接 照明でなく，アンブレラを介した乱反射光である ため, ソフトな立体感のある顔貌撮影が可能であ $ろ^{4,5)}$.
4. マルチ・ケーブルレリーズ

今回の撮影法には電磁式レリーズを用いた。従 来のメカニカル・シャッター・レリーズではタイ ム・ラグなしにはレリーズすることが不可能であ る.したがって, 著者のは図 4 に示すようにレリー 


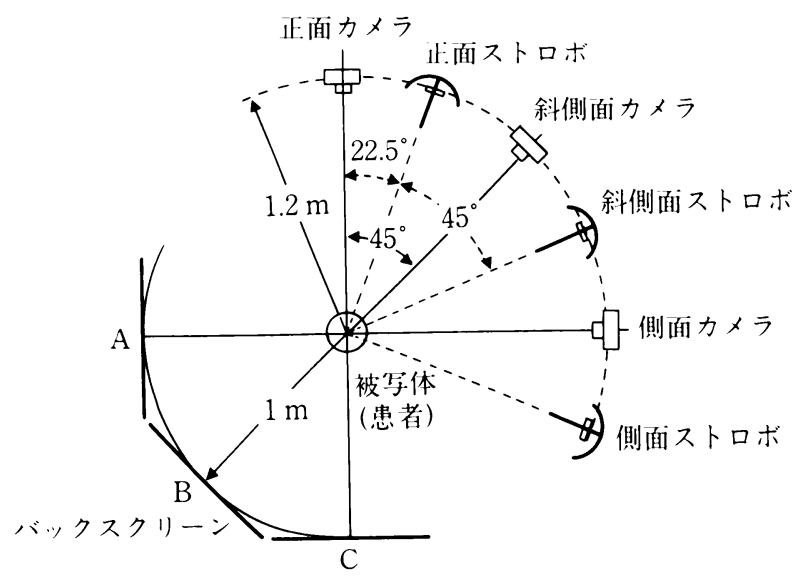

図 5 マルチ・レリーズシステム配置図

被写体とカメラ, ストロボ, アンブレラならびに

バックスクリーンの配置

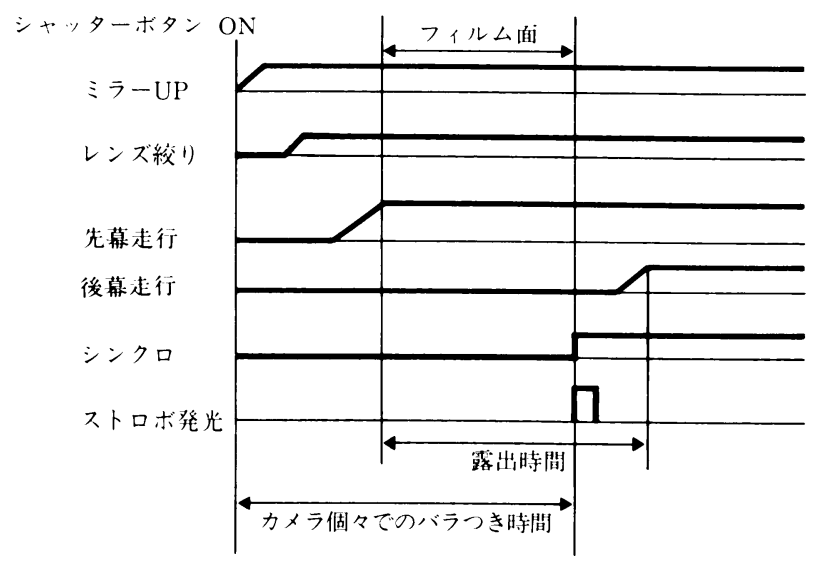

図 6 カメラ作動夕イミング・チャート

ズを自家開発し組み立て，一体化し接続したもの である。これには以下に述べる事項を十分考慮し なければならなかった。

\section{5.カメラ作動タイミング（絞り連動タイム）}

それぞれのカメラには，作動夕イミングのわず かなづれがあるため，3 台のカメラのストロボを 完全に同調させることは不可能で, この点が最も 苦心した点である.すなわち, シャッターボタン を押し，ストロボ発光までに個々のカメラにより 時間差が約数ミリ・セカンドのオーダーで認めら れるが (図6)，このオーダーではマルチ・ケーブ ルレリーズの使用により，ストロボ発光の時間差 をほほ同時にすることができた。

\section{規格撮影法の決定}

\section{1. テスト撮影}

まず，図 3 に示すように正面からの正貌撮影を 何度もくり返し撮影し, 露出を決定した. 表 1 は こうして得られた著者の適正撮影データーを示 す.

したがって，このテスト撮影により適正規格撮 影データーを決定しておけば，コンスタントに適 正な露出の写真が得られる.

\section{2. 正・斜・側貌規格同時撮影法の決定}

上記のテスト撮影結果により撮影条件を決定し 
た後，図 4，5に示すように 3 台のカメラ，アン ブレラおよびマルチ・ケーブルレリーズ（以下レ リーズと略記する）をおのおのの位置に設置し， シャッターは一カ所に集積されたレリーズによっ て 3 カ所のカメラが同時に作動する仕組みに構成 した。患者とそれぞれのカメラの設置位置(距離) は図 5 に示す通りである。

表 1 顔貌撮影データー

\begin{tabular}{l}
\hline 患者とバックとの距離 $\rightarrow 1.0 \mathrm{~m}$ 以上 \\
影消し用ストロボ・ガイドナンバー \\
$\rightarrow \mathrm{G} . \mathrm{N} .(\mathrm{ISO} 100) 14$ \\
アンブレラの高さ $\rightarrow 2.0 \mathrm{~m}$ \\
患者に対するバウンズ光の主線方向 \\
$\quad \rightarrow$ 斜 $45^{\circ}$ 前上方より $30^{\circ} \sim 45^{\circ}$ 入射 \\
\hline
\end{tabular}

\section{撮影結果ならびに検討}

著者は顔貌一面規格撮影法を基に，考案開発し た 3 面顔貌規格同時撮影法を確立したが，それに よって得られた患者の術前・術後の正貌・斜貌・ 側貌での 3 面規格写真は図 7 a , b , c (術前) ならびに図 $8 a, b, c$ (術後) に示す通りであ る.

すなわち，上記結果から検討すると，顔貌写真 は歯科医学上, ことに臨床上, 種々な場面で, そ れぞれ目的に応じて必要欠くべからざるものであ る.

著者は既に顔貌撮影法（規格撮影ならびに自由 撮影)に関する術式を確立し報告した(図 1，2）。 今回の 3 面顔貌規格同時撮影法は，ストロボ発光
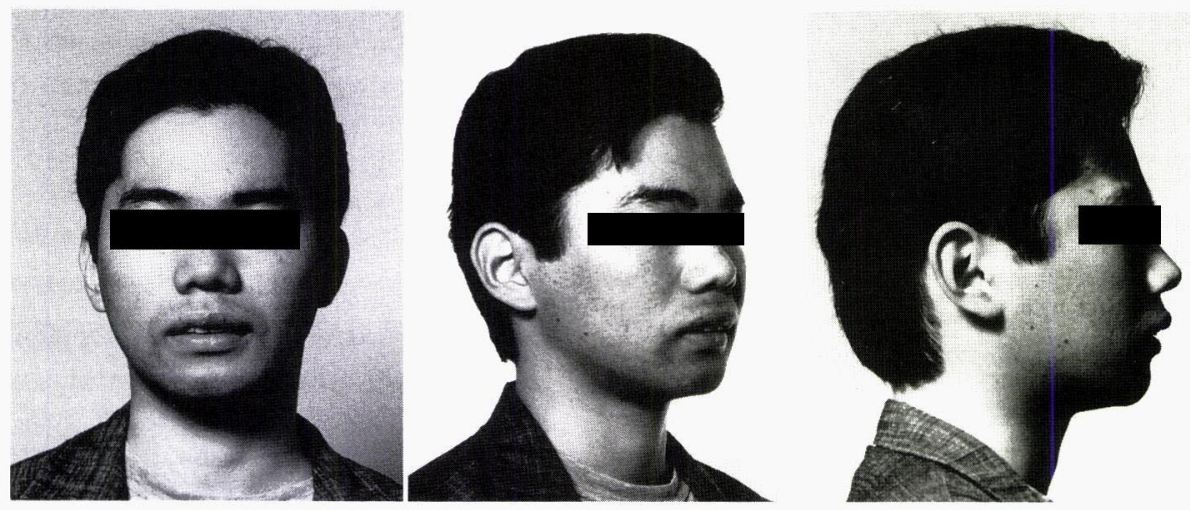

図 7 術前の 3 面顔貌規格写真(上䫈前突)

a : 正貌 (写真左), b : $45^{\circ}$ 斜側貌 (写真中央), c : 側貌 (写真右)
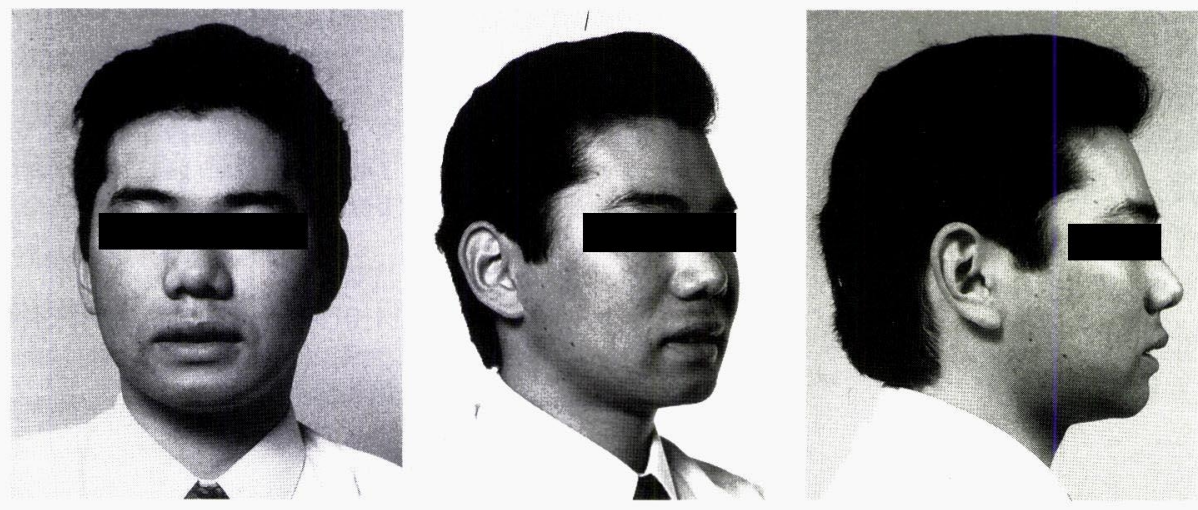

図 8 術後の 3 面顔貌規格写真

a : 正貌 (写真左), b : 45 斜側貌 (写真中央), c : 側貌 (写真右) 
時間が個々のカメラにより絞り運動時間の差が見 られるため，微調整することによって今回の撮影 法が可能となった。その場合，一定の規格に従っ た基準が必要となり，これなくして写真による比 較ならびに評価ができなく，臨床写真としての価 值少ない.

自由撮影の場合では，適切な距離から自然な表 情のシャッター・チャンスを狙えば良いのであっ て，最も自然で普遍的な表情の一駒が記録される のである。これは一点凝視条件下での 3 面規格に よる条件下とは異なるものとなる。

したがって，規格撮影法は自由撮影での一般の 芸術的な人物撮影と異なる点である.

マルチ・レリーズシステムの必要性は, 各撮影 面が 3 方向から同時瞬間的に記録されるところに 特徴がある。

理論的には，すべて同時発光して，同一条件で 撮影されるわけであるが，開発当初，それぞれの ストロボとカメラとの同調が困難で撮影に失敗 し，原因が解明できず苦労したが，それは絞り連 動時間の差であることが判明した。この発光時間 のズレが 3 台のカメラを同時同調させられない理 由であった。この点が，本法の考案に際して最も 苦労した点であった。

したがって, 従来の 1 面毎の各個 3 面顔貌写真 では規格化が困難であるのは勿論であるし，撮影 に時間がかかるため，患者自身にとっても，喜ば れない.

また,大型鏡を用いた反射 2 面同時撮影法では， ガラス表面加工（反射率の問題等）ならびに角度 調節の点からも，種々の欠点をも含んでいる.

顔貌撮影の要点としては，1）撮影目的に対す る患者の認識, 理解および協力を得ること，2）規 格撮影の原則を厳守すること(カメラの設置距離, 高さ，角度など)，3）機器の選択を的確にするこ と，4）スタンドとレリーズを使用して,カメラ・ ブレを防止すること，5）自由撮影においては, 患者の最も自然な表情でのシャッター・チャンス を恛むこと，などである。

\section{むすび}

著者は，既に報告している 1 面規格撮影法を基 として考案開発した 3 面顔貌規格同時撮影法を臨 床応用した結果，以下の結論を得た。

1. 3 台の撮影装置を用いることによって，顔 貌の 3 面撮影法の規格化を確立することができ た.

2.マルチ・ケーブルレリーズによる発光時間 の同調によって、各カメラの瞬間同時撮影が可能 になった。

なお，今回の撮影装置の設置には，広い空間を 要するので, 現下の歯科診療施設では制約があり, 困難な状況が想定される。

また現時点での装置では反対側規格同時撮影は 困難で, $180^{\circ}$ 撮影については未解であり, 今後の検 討課題である。

稿を終えるに際し，理論的ならびに技術的な面で 種々ご指導を頂いた，野でんちか天雄氏 に深く謝意を表します。

\section{参考文献}

1) 熊谷 崇, 熊谷ふじ子：口腔内写真の撮り方。 医歯薬出版 (東京), 1992 .

2）清野 尚, 増田純一, 他：デンタル・イマジネー ションーその技とこころの記録一.12-23，クイ ンテッセンス出版 (東京), 1987 .

3）清野 尚：アドバンス臨床写真コース.クイン テッセンス出版 (東京), 1994 。

4）三木 淳, 他：写真大辞典. 176-184，549-555, 講談社 (東京), 1984.

5）吉川八百美：ポートレート撮影ハンドブック。 玄光社 (東京), 1990 .

6) Bengel, W. : Die Photographie in Zahnmedizin u. Zahntechnik, 214-218, Quintessenz Verlag (Berlin), 1984.

別刷請求先：清野 尚 